\title{
Niveles de Bifurcación Aórtica en Individuos Chilenos
}

\author{
Aortic Bifurcation Levels in Chilean Individuals
}

${ }^{*}$ Puelma, F. \& ** Olave, E.

\begin{abstract}
PUELMA, F. \& OLAVE, E. Niveles de bifurcación aórtica en individuos chilenos. Int. J. Morphol., 27(4):1335-1338, 2009.
RESUMEN: Durante el abordaje anterior de la región lumbosacra de la columna vertebral es necesario considerar la disposición de los vasos relacionados, evitando así cualquier lesión en ellos. La información sobre la bifurcación de la aorta referida en los textos de anatomía señalan que ésta se realiza a nivel de la cuarta vértebra lumbar. Con el propósito de identificar el nivel de bifurcación de la aorta, realizamos un estudio de registros angiotomográficos obtenidos a través de tomografia axial computarizada de 74 pacientes chilenos, adultos, de ambos sexos, 40 hombres y 34 mujeres. El nivel de bifurcación fue relacionado con los componentes de la columna vertebral, dividiendo las vértebras en tercios. En 10 pacientes (13,5\%) la bifurcación se observó a nivel de la parte inferior de L3; en 17 (23\%) en la parte superior de L4; en $8(10,8 \%)$ en la parte media de L4; en $26(35,1)$ en la parte inferior de L4; en 9 (12,2\%) en la parte superior de L5 y en $4(5,4 \%)$ en la parte inferior de L5.Los resultados obtenidos muestran que en la mayoría de los individuos estudiados la bifurcación de la aorta se produce a nivel de L4, existiendo menores porcentajes hacia la parte cefálica o caudal de la vértebra mencionada. Esta relación es un aporte al conocimiento anatómico de los vasos abdominales de nuestra población
\end{abstract}

PALABRAS CLAVE: Anatomía; Aorta; Bifurcación aórtica; Vértebras lumbares.

\section{INTRODUCCIÓN}

El conocimiento de la anatomía vascular es de gran importancia durante los procedimientos quirúrgicos, por lo que es necesario conocer los padrones más frecuentes y las variaciones respectivas. La aorta, siendo la más grande de las arterias, ha sido bien descrita en los textos de anatomía, donde se considera su trayecto, relaciones y ramas que emite durante su largo recorrido. Generalmente se bifurca en sus ramas terminales a nivel de la vértebra L4 (Testut \& Latarjet, 1969; Williams et al., 1995; Moore \& Dalley, 2002). Sin embargo, puede terminar a niveles más altos o más bajos que lo mencionado.

Pirró et al. (2005) describieron a la bifurcación aórtica entre las vértebras L3 y L5, observando más frecuentemente ésta a nivel de la vértebra L5 en $50 \%$ de sus casos.

En un estudio realizado recientemente en 187 cadáveres, Khamanarong et al. (2009) observaron que la aorta se bifurcó a nivel de la vértebra L4 en 70,1 \% de los casos y a nivel de la vértebra L5 en 17,6\%.
La literatura también muestra casos raros de bifurcación como el referido por Kara et al., (2008) donde la arteria ilíaca externa derecha se originó a nivel de las últimas arterias lumbares y caudal a ella, la aorta se bifurcó en arteria ilíaca interna derecha y arteria ilíaca común izquierda.

Basado en lo anteriormente mencionado y siendo de utilidad para los cirujanos, localizar con precisión la bifurcación aórtica durante el abordaje anterior de la columna lumbosacra, nos propusimos analizar este punto en un grupo de pacientes de la población chilena, considerando su relación con la columna vertebral y determinando su nivel con partes de cada una de las vértebras asociadas.

\section{MATERIAL Y METODO}

En este estudio fueron utilizados los registros angiotomográficos de 74 pacientes, chilenos, adultos, de

\footnotetext{
Facultad de Medicina, Universidad Católica del Maule, Chile. programa de Magister en Ciencias, mención Morfología, Universidad de La Frontera, Temuco, Chile.

** Facultad de Medicina, Universidad de La Frontera, Chile.
} 


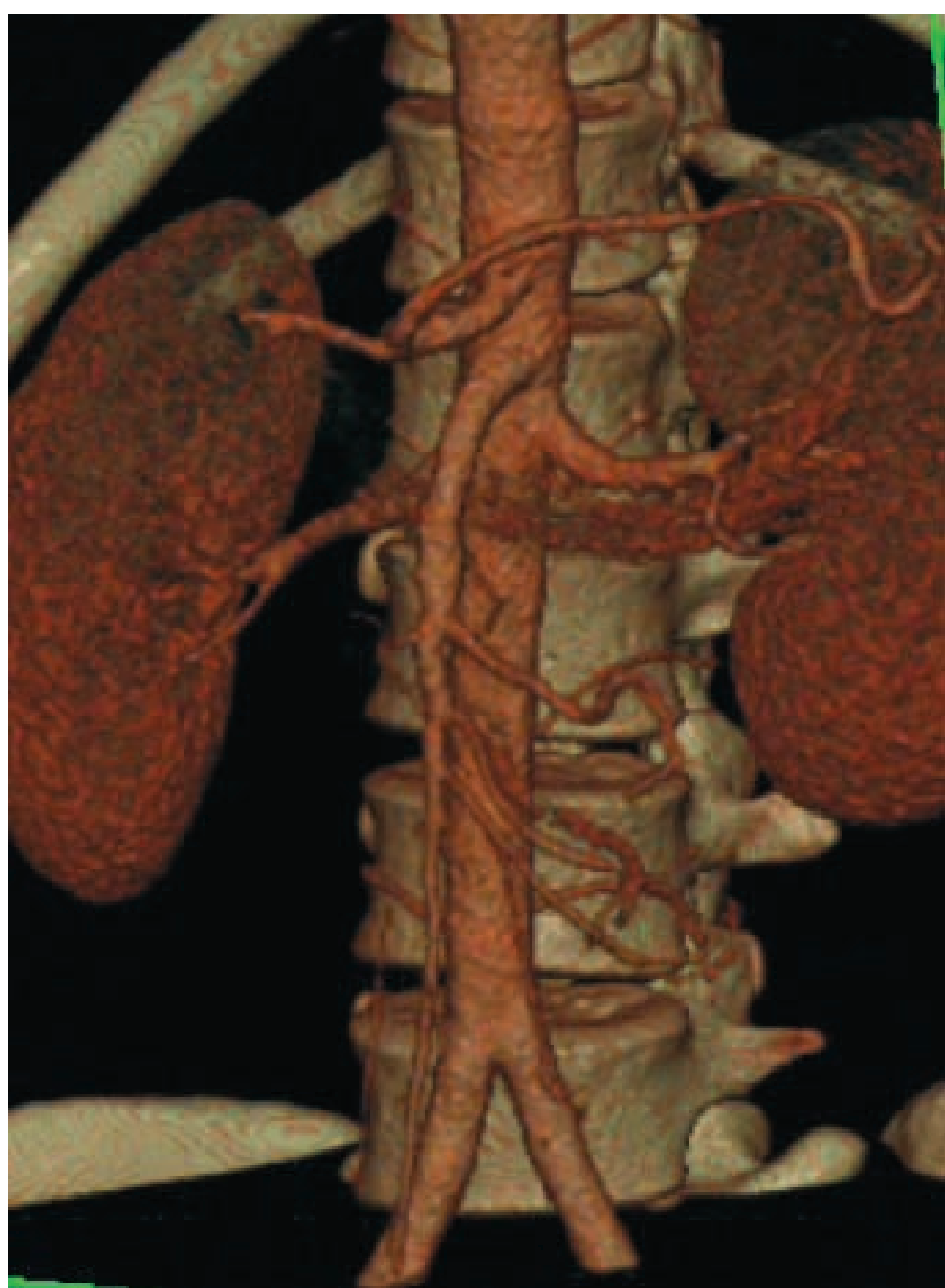

Fig. 1. Bifurcación aórtica a nivel de la parte superior de la vértebra L4. ambos sexos, 40 hombres y 34 mujeres, los que fueron obtenidos a través de tomografía axial computarizada helicoidal multidetectores. En ellas se observó el nivel de bifurcación de la aorta en relación a la columna vertebral, considerando en cada una de las vértebras relacionadas tres partes: superior, media e inferior para la referida relación. Cada uno de los registros fue esquematizado y se obtuvieron las fotografías de las imágenes más representativas.

\section{RESULTADOS}

La aorta fue única y su bifurcación fue observada en todos los casos $(100 \%)$. Observamos la bifurcación a nivel de la vértebra L3 en 10 casos (13,5\%); a nivel de la vértebra L4 en $51(68,9 \%$, Fig. 1) y a nivel de la vértebra L5 en $13(17,6 \%)$. Por sexos, ésta se observó a nivel de la vértebra L3 en 6 casos del sexo masculino y en 4 del femenino; relacionada con la vértebra L4, 25 casos del sexo masculino y 26 del femenino y a nivel de L5, 9 casos del sexo masculino y 4 del femenino. La relación con las partes superior, media e inferior de las vértebras mencionadas es mostrada en la Tabla I.

La bifurcación mas cefálica encontrada correspondió al tercio inferior de L3 (Fig. 2) y la más caudal a nivel del tercio superior de L5 (Fig.3).

Tabla I. Niveles de bifurcación aórtica y su relación con la columna vertebral, considerando sexo y tercios de los cuerpos vertebrales

\begin{tabular}{lccccc}
\hline Vértebra & \multicolumn{2}{c}{ Sexo masculino } & \multicolumn{2}{c}{ Sexo femenino } & \\
\hline & Casos & $\%$ & Casos & $\%$ & Total casos \\
Parte inferior L3 & 6 & 15 & 4 & 11,8 & 10 \\
Parte superior L4 & 12 & 30 & 5 & 14,7 & 17 \\
Parte media L4 & 5 & 12,5 & 3 & 8,8 & 8 \\
Parte inferior L4 & 8 & 20 & 18 & 52,9 & 26 \\
Parte superior L5 & 7 & 17,5 & 2 & 5,9 & 9 \\
Parte media L5 & 0 & 0 & 0 & 0 & 0 \\
Parte inferior L5 & 2 & 5 & 2 & 5,9 & 4 \\
\hline Total & 40 & 100 & 34 & 100 & 74 \\
\hline
\end{tabular}




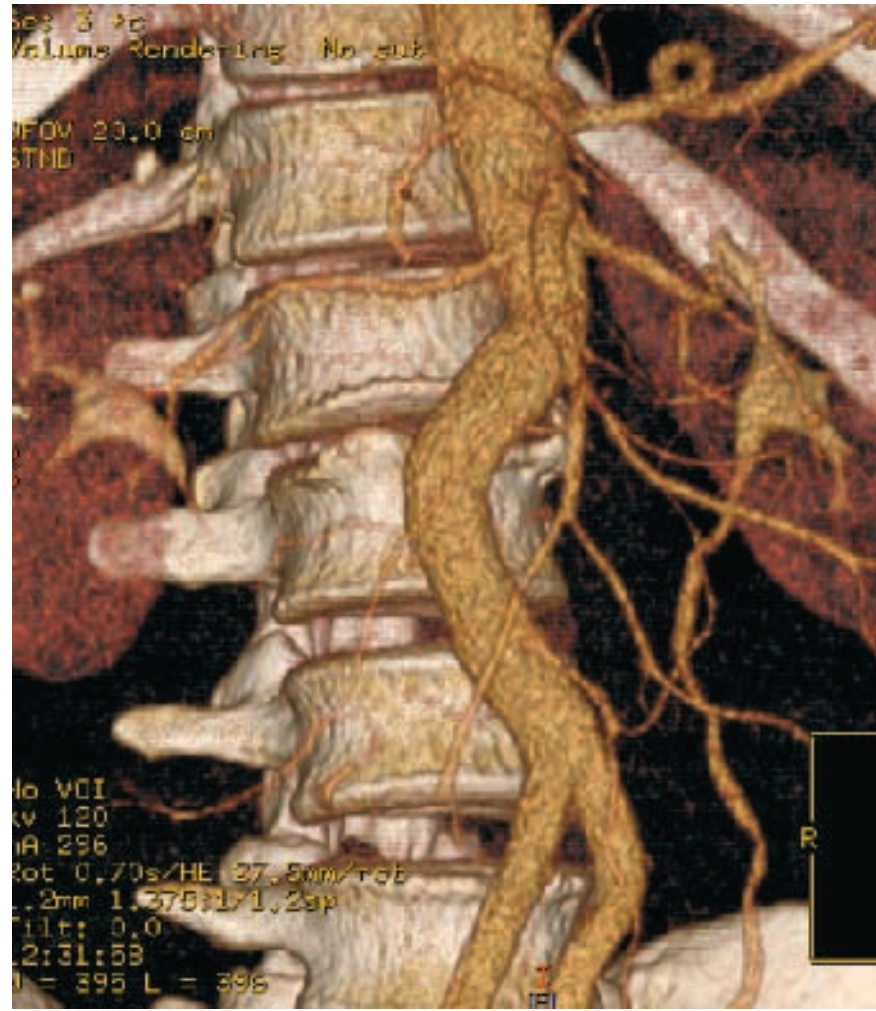

Fig. 2.Bifurcación aórtica a nivel de la parte inferior de la vértebra L3.

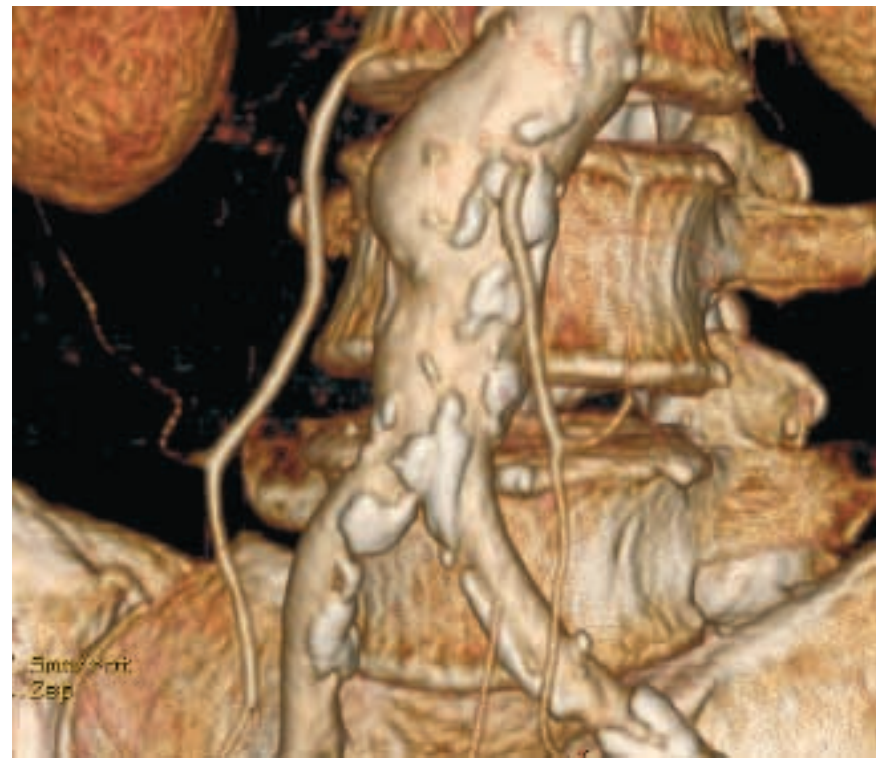

Fig. 3. Bifurcación aórtica a nivel de la parte superior de la vértebra L5.

\section{DISCUSIÓN}

La parte abdominal de la aorta se extiende desde el nivel de la vértebra T12 hasta su bifurcación a nivel de la vértebra $L 4$, situada levemente a la izquierda de la línea media, donde se divide en arterias ilíacas comunes (McKears \& Owen, 1979). El punto de localización del nivel mencionado ha sido descrito por varios autores, entre los cuales se puede mencionar a Testut \& Latarjet; Williams et al. y Moore \& Dalley. Sin embargo, se ha mencionado que a veces puede bifurcarse a un nivel más alto o más bajo.

Nuestros resultados de bifurcación aórtica a nivel de L4 en $68,9 \%$ y a nivel de L5 en $17,6 \%$ del total de casos estudiados, son concordantes con los publicados por Khamanarong et al., quienes en 187 cadáveres observaron que esta bifurcación ocurrió a nivel de la vértebra L4 en 70,1\% y a nivel de la vértebra L5 en 17,6 $\%$.

Autores como Chithiriki et al. (2002) a través de resonancia magnética, encontraron esta división a nivel de L4 en 67\% de sus 441 casos; Inamasu et al. (2005) en un grupo de 100 pacientes y a través de tomografía computarizada, la observaron en $55 \%$ a este nivel y en L5 en 18\%, y, Lakchayapakorn \& Siriprakarn (2008) estudiando 65 cadáveres, la encontraron a nivel de L4 en $63 \%$, resultados con los que concordamos.

Por su parte, Pirró et al. indicaron a esta bifurcación entre las vértebras L3 y L5, observándola a nivel de la vértebra L5 en $50 \%$ de los 42 cadáveres investigados, porcentaje muy superior a los de nuestra población.

En estudio realizado previamente por Kawahara et al. (1996) se señaló que en una serie de 21 cadáveres, la bifurcación se observó a nivel de L4 en 38,1\% y entre L4 y L5 en 42,8\% de los casos, encontrando sólo 1 caso a nivel de L3 y otro a nivel de L5.

Los resultados más detallados, considerando partes de las vértebras relacionadas a la bifurcación, difieren de los obtenidos por Chithriki et al., quienes encontraron el nivel de la división en la parte superior de L4 en $19,1 \%$, poco menor al $23 \%$ de nuestra serie; en la parte media de esta vértebra en $24 \%$, superior a nuestro resultado de $10,8 \%$ y en la parte inferior de la vértebra mencionada en $23,8 \%$ diferente del $35,1 \%$ obtenido en esta investigación.

Sabiendo de la importancia que tiene conocer con detalle la disposición de los vasos relacionados con la columna lumbosacra, en nuestra población la bifurcación ocurre mayoritariamente a nivel de L4 y en menor porcentaje a nivel de L3 y L5.

Resulta interesante observar que en el sexo masculino, el nivel de bifurcación aórtica se presenta con más frecuencia a nivel de la parte superior de L4, obser- 
vándose desde la parte media de este cuerpo vertebral hacia arriba en un $42,5 \%$. En cambio, en el sexo femenino este nivel es más inferior, o sea, desde la parte media de esta vértebra hacia abajo, encontrándose en un $61,7 \%$. Esta diferencia podría deberse a la talla de los individuos estudiados, aunque no consideramos esa variable.

Chithriki et al. encontraron 8,4\% (37 casos) de anomalías lumbosacras en el grupo estudiado, señalando que en pacientes con sacralización de la vértebra L5, la bifurcación aórtica la observaron a un nivel más cefálico (L3 en $59 \%$ y cuando hubo lumbarización de la vértebra S1 el nivel fue más caudal (L4 y L5 en 33\%). En nuestro estudio no observamos tales anomalías.
Se han reportado también casos raros de terminación de la aorta, donde la arteria ilíaca externa derecha se originó a nivel de las últimas arterias lumbares y caudal a ella, la aorta se dividió en arteria ilíaca interna derecha y arteria ilíaca común izquierda (Kara et al.), situación que no hemos observado en nuestra casuística.

Los actuales aparatos de imágenes nos permiten realizar detalladas observaciones de las diversas estructuras anatómicas en individuos vivos, de tal modo que los resultados obtenidos nos permiten tener una clara visión del nivel donde ocurre la bifurcación aórtica en la población chilena, lo que redunda en un aporte al conocimiento anatómico de la región.

PUELMA, F. \& OLAVE, E. Niveles de bifurcación aórtica en individuos chilenos. Int. J. Morphol., 27(4):1335-1338, 2009.

SUMMARY: During the anterior approach of the lumbosacral spine is necessary considerate the relationships with the vascular system to prevent injuries. The classic anatomy texts describe the aortic bifurcation to level of fourth lumbar vertebra. The objective of this research was determine this level in Chilean individuals. We studied the aortic bifurcation by axial computed tomography in 74 patients, Chilean, adults, of both sexes, 40 men and 34 women. The mentioned level was related with the lumbar vertebras, dividing its body in third parts. We observed the bifurcation at level of inferior third of L3 in 10 patients (13.5\%); in the superior third of L4 in 17 (23\%); in the middle third of L4 in 8 (10.8\%); in the inferior third of L4 in 26 (35.1\%); in the superior third of L5 in $9(12.2 \%)$ and in the inferior third of L5 in $4(5.4 \%)$. The results shown that in $2 / 3$ of the cases the aortic bifurcation was to L4 level, being less frequent in proximal or distal vertebras. These relationships are important for the anatomical knowledge of the abdominal vascular system of our people.

KEY WORDS: Anatomy; Aorta; Aortic bifurcation; Lumbar vertebras.

\section{REFERENCIAS BIBLIOGRÁFICAS}

Chithriki, M.; Jaibaji, M.; Steele, R.D. The anatomical relationship of the aortic bifurcation to the lumbar vertebrae: a MRI study. Surg. Radiol. Anat., 24:308-312, 2002.

Inamasu, J.; Kim, D.H. \& Logan, L. Three-dimensional computed tomographic anatomy of the abdominal great vessels pertinent to L4-L5 anterior lumbar interbody fusion. Minim. Invasive Neurosurg., 48(3):127-31, 2005.

Khamanarong, K.; Sae-Jung, S.; Supa-Adirek, C.; Teerakul, S. \& Prachaney, P. Aortic bifurcation: a cadaveric study of its relationship to the spine. J. Med. Assoc. Thai., 92(1):47-9, 2009.

Kara, E.; Yildiz, A.; Öztürk, N. \& Öztürk, H. An extremely rare bifurcation pattern of the caudal abdominal aorta: case report demonstrated by angiography. Surg. Radiol. Anat., 30:689-91, 2008.

Kawahara, N.; Tomita, K.; Baba, H.; Toribatake, Y.; Fujita, T.; Mizuno, K. \& Tanaka, S. Cadaveric vascular anatomy for total en bloc spondylectomy in malignant vertebral tumors. Spine (Phila a 1976), 21(12):1401-7, 1996.

Lakchayapakorn, K. \& Siriprakarn, Y. Anatomical variations of the position of the aortic bifurcation, iliocava junction and iliac veins in relation to the lumbar vertebra. J. Med. Assoc. Thai., 91(10):1564-70, 2008.
McKears, D.W. \& Owen, R. H. Surface Anatomy for Radiographers. Bristol, John Wright \& Sons Ltd., 1979.

Moore, K.. \& Dalley, A. F. Anatomía con orientación Clínica. $4^{\mathrm{a}}$ Ed. Buenos Aires, Panamericana, 2002.

Pirró, N.; Clampi, D.; Champsaur, P. \& Di Marino, V. The anatomical relationship of the iliocava junction to the lumbosacral spine and the aortic bifurcation. Surg. Radiol. Anat., 27:137-41, 2005.

Testut, L. \& Latarjet, A. Tratado de Anatomía Humana. Barcelona, Salvat, 1969.

Williams, PL; Warwick, R.; Dyson, M. \& Bannister, LH. Gray Anatomia. $37^{\text {th }}$ Ed. Rio de Janeiro, Guanabara Koogan, 1995.

Dirección para correspondencia:

Prof. Dr. Enrique Olave

Facultad de Medicina

Universidad de La Frontera

Casilla 54-D

Temuco - CHILE

Email: eolave@ufro.cl

Recibido : 22-09-2009

Aceptado: 29-10-2009 


\title{
Effect of Urtica dioica L Extract on Quantitative Morphometric Alterations of Liver Parenchymal Cells in STZ Diabetic Rats
}

\author{
Efecto del Extracto de Urtica dioica sobre Alteraciones Morfométricas \\ Cuantitativas de las Células del Parénquima Hepático en Ratas STZ Diabéticas
}

"Mohammad Jafar Golalipour; **'Soraya Ghafari \& ${ }^{* * *}$ Mir Mehrdad Farsi

GOLALIPOUR, M. J.; GHAFARI, S. \& FARSI, M. M. Effect of Urtica dioica extract on quantitative morphometric alterations of liver parenchymal cells in STZ diabetic rats. Int. J. Morphol., 27(4):1339-1344, 2009.

SUMMARY: Diabetes is associated with several structural and functional liver abnormalities that affect glycogen and lipid metabolism. In this study, an attempt was made to evaluate the effects of hydroalcoholic extract of Urtica dioica leaves on Quantitative morphometric changes in parenchymal cells of the livers in STZ diabetic rats. Thirty male Wistar rats were allocated in 3 groups: normal, diabetic and treatment. Hyperglycemia was induced by $80 \mathrm{mg} / \mathrm{kg}$ Streptozotocin intraperitoneally. One week after the injection of STZ, the third group received the hydroalcoholic extract of Urtica dioica at $100 \mathrm{mg} / \mathrm{kg} / \mathrm{day}$ over four weeks. After five weeks, the animals were sacrificed and whole livers were removed. Liver specimens were used for quantitative morphometric analyze after hematoxylin and eosin staining. All data are shown as means plus standard errors of means and were analyzed using One-Way ANOVA test at $\mathrm{P}<0.05$.The mean area of hepatocytes, nuclei and nucleolus had a decrease in periportal zone and an increase in perivenous zone in the diabetic and treatment groups. The increase of hepatocyte area in perivenous zone and reduce of nucleus area in periportal zone was significant in the diabetic group in comparison with control group $(\mathrm{P}<0.05)$, but were not significant between treatment and diabetic group. This study showed that administration of $100 \mathrm{mg} / \mathrm{kg} /$ day of Urtica dioica leaves extracts after induction of diabetes can cause a little modulating in the main morphometric indices of liver such as area of hepatocytes, nuclei and nucleolus in periportal and perivenous zones.

KEY WORDS: Diabetes; Urtica dioica; Liver; Hepatocyte; Morphometry.

\section{INTRODUCTION}

Diabetes is a chronic disease with a relatively high prevalence in many populations across the world (Jerrold, 2000). Diabetes is associated with several structural and functional liver abnormalities that affect glycogen and lipid metabolism (Sanchez et al., 2000; Koyuturk et al., 2005; Bolkent et al., 2004). The liver plays a central and crucial role in the regulation of carbohydrate metabolism. Thus it uses glucose as a fuel and also has the ability to store it as glycogen, and it synthesizes this from noncarbohydrate precursors (gluconeogenesis) (Levinthal \& Tavill, 1999).

Despite the availability of many synthetic drugs a large number of diabetic patients seek herbal medication to relieve the symptoms of the disease (Bennett \& Brown, 2000; Ryan et al., 2001).

Urtica dioica L. (U. dioica) is a plant belong to the plant family Urticaceae. This herb is widely used in folk medicine for improving certain diseases such as diabetes (Kavalali et al., 2003; Roman Ramos et al., 1992; Petlevski et al., 2003; Farzami et al., 2003), rheumatoid arthritis, hypertension and allergic rhinitis (Mittman, 1990; Sezik et al., 1997; Riehemann et al., 1999).

The inhibitory, antioxidative, antidiabetic and antitoxic effects of $U$. dioica on the liver in diabetes have

\footnotetext{
* Professor, Department of Anatomical Sciences (Histology and Embryology), Gorgan University of Medical Sciences, Gorgan, Iran.

** Department of Anatomical Sciences (Histology and Embryology), Gorgan University of Medical Sciences, Gorgan, Iran.

**** Assistant Professor, Department of Anatomy, Babol University of Medical Sciences, Babol, Iran
} 